Walaa Shoupk, et al, Theoretical Study on Static Shear Behavior of High Strength Concrete Beams Compared with Normal Strength Concrete Beams, pp. 1753 - 1764

\title{
THEORETICAL STUDY ON STATIC SHEAR BEHAVIOR OF HIGH STRENGTH CONCRETE BEAMS COMPARED WITH NORMAL STRENGTH CONCRETE BEAMS
}

\author{
Khairy Hassan Abdel Kareem ${ }^{1}$, Fayez Kaiser Abdel Sayed ${ }^{2}$ and Walaa Shoupk ${ }^{3, *}$ \\ ${ }^{1}$ Professor of concrete structures, Faculty of Engineering, Assiut University \\ ${ }^{2}$ Civil Engineer, Ministry of Water resources and Irrigation
}

Received 21 August 2013; accepted 25 September 2013

\begin{abstract}
The main aim of the present study is to present a comparison between the static shear behavior of high strength concrete beams and normal strength concrete beams. The concrete compressive strength of the beams ranged from 250 to $700 \mathrm{~kg} / \mathrm{cm}^{2}$. Sixty reinforced concrete beams were analyzed under two point static loads. The variables were the compressive strength of concrete, shear span-to-depth ratio and shear reinforcement ratio (stirrup spacing $S$ ). The effect of each variable on the behavior of the beams is studied separately. The details of the beam specimens, material properties, and instrumentation are described in this paper. The results are presented and discussed and the influence of each design parameter is investigated. Analysis of the results is also compared with different existing approaches.
\end{abstract}

Keywords: Normal and High-strength concrete Beams, Shear reinforcement, Spacing of stirrup, Shear span to depth ratio, Cracking and Ultimate shear strength.

\section{Introduction}

In recent times, high strength concrete has been used widely in construction. For example Beams, Columns, Precast elements and Structures where durability is an important design parameter. This has resulted in the design of beams of smaller depths, which may undergo greater deflections. To give a simplified explanation, HSC is obtained by improving the compactness of the concrete mix, which increases the strength of both the paste and the interface between the paste and the coarse aggregate. However, an increase in the strength of the concrete produces an increase in its brittleness and smoother shear failure surfaces leading to some concerns about the application of high-strength concrete.

Since most of the current shear procedures are based on tests carried out on beams with a concrete compressive strength lower than $401.1 \mathrm{~kg} / \mathrm{cm}^{2}$ and one of the shear transfer mechanisms is shear-friction across the cracks, the failure shear strength needs to be reevaluated. Moreover, shear failure in a beam without web reinforcement is sudden and brittle. Therefore, it is necessary to provide an amount of shear reinforcement, which must prevent sudden shear failure on the formation of first diagonal tension cracking and, in addition, must adequately control the diagonal tension cracks at service load levels.

Due to the higher tensile strength of high strength concrete, a higher cracking shear is expected and hence, would require a large amount of shear reinforcement. In some codes of practice, the shear strength of a reinforced concrete beam is taken as the sum of the

Corresponding author.

E-mail address: wallashoupk@hotmail.com 
Walaa Shoupk, et al, Theoretical Study on Static Shear Behavior of High Strength Concrete Beams Compared with Normal Strength Concrete Beams, pp. 1753 - 1764

shear force that is carried by the concrete $\left(^{V}\right)$ and the web reinforcement $\left({ }^{V}\right)$. The term $V^{(c)}$ in a diagonally cracked beam with web reinforcement represents the sum of three separate components. These components are:

(a) Dowel action resistance of the longitudinal reinforcement,

(b) Aggregate interlock resistance along the diagonal crack,

(c) The shear resistance carried by the uncracked concrete compressive zone.

The term $\left({ }^{V}\right)$ represents the vertical component of the shear force carried by the vertical (shear) reinforcement (strut mechanism).

\section{Research Significance}

This research was carried out for the following purposes:

1- To study the effect of compressive strength, a/d ratio, shear reinforcement and Ultimate shear strength of reinforced high strength concrete beams of rectangular cross section.

2- To compare the obtained analysis results and proposed equations results with the ACI Code.

\section{Previous Works}

Experimental tests were carried out to get a better understanding of the behavior of shear strength of high strength concrete beams and to estimate the amount of the shear reinforcement required to high strength concrete beams in order to prevent sudden failure of the beam and to improve its ductility. In ref. (1), the authors carried out a study to make a comparative analysis on shear behavior of high-strength concrete beams using various international design approaches like ACI [1], Canadian [2], AASHTO [3], European Code [4] and the method proposed by Zararis [5]. Reinforced concrete beams without web reinforcement were tested under three point loading. Based on the analysis of total of 122 similar beams, they observed that:

1- When shear span-to-effective depth ratio increases from 2 to 3 , relative flexural strength decreases, however, this decrease is dependent upon the tensile steel ratio as the greater the steel ratio, the lower is the difference. On further increase of a/d ratio from 3 to 6 , the relative flexural strength increases and a valley of diagonal shear failure was observed in the vicinity of shear span-to-depth ratio equal to 3 .

2- For a constant value of a/d ratio, the relative flexural strength decreases and failure load increases with an increase in longitudinal reinforcement ratio.

3- Comparison of test results with various approaches reveals that the experimental shear strength is more in conformity with ACI 318-02 than other design approaches for beams having tensile steel ratio higher than $1 \%$. Current ACI 318 shear strength equation could be not conservative for lightly reinforced high-strength concrete beams having tensile steel ratio $<0.58 \%$.

4- The current shear design approaches in various codes underestimate the shear carrying capacity of high-strength concrete beams up to shear span-to-depth ratio 2.5 and overestimate for slender beams having a/d ranging from 2.5 to 6 .

Journal of Engineering Sciences, Assiut University, Faculty of Engineering, Vol. 41, No. 5, September, 2013, E-mail address: jes@aun.edu.eg 
Walaa Shoupk, et al, Theoretical Study on Static Shear Behavior of High Strength Concrete Beams Compared with Normal Strength Concrete Beams, pp. 1753 - 1764

5- Analysis of the research results revealed that shear strength and failure mode depends on shear span and longitudinal reinforcement ratio.

In ref. (2) An experimental investigation was carried out to study the shear behavior of (HSC) beams with constant width by varying shear span to depth ratio, the longitudinal reinforcement ratio and the minimum web reinforcement ratio. They compared the results with the different code equations and concluded that the longitudinal reinforcement ratio, strength of the concrete, shear span to depth ratio, value and depth of the beam are the most influencing parameters in the deformational and shear behavior of the HSC slender beams with web reinforcement. The result indicates that the reserve strength, increases with increase in the percentage of longitudinal reinforcement ratio. And as the longitudinal reinforcement ratio increases, the ultimate shear stress increases. He also found that as the shear span to depth ratio $(\mathrm{a} / \mathrm{d})$ increases,

In ref. (3), the authors carried out a study on shear resistance of high strength concrete beams. The shear span-to-effective depth ratio is taken as main variable keeping all other parameters constant.

Most of the equations are under estimating the shear capacity at lower a/d ratios.

When the a/d ratio is less than (2.0), strut action prevails and the shear resistance is very high. For a/d ratios up to (2), the experimental values showed remarkable increase in $\mathrm{s}$ hear strength compared to various design approaches.

In ref. (4) The authors carried out a study to predict the shear strength of high strength concrete beams (70 Mpa) with different shear span to depth ratios without web reinforcement. The reinforced concrete beams were tested under shear loading and were modeled in 'ANSYS', which is Finite Element Analysis software. The test results were compared with the 'ANSYS' model results

They indicate that the increase in a/d ratio has shown reduction in shear capacity of the beam. At lower a/d ratios the ultimate load was observed to be more than twice at diagonal cracking. The deflections increased with a/d ratio. The ANSYS model closely predicted the diagonal tension failure and shear compression failure of high strength concrete beams without shear reinforcement as observed in experiment.

\section{Theoretical Program}

\section{1. Analyzed beams}

We analyzed sixty reinforced concrete beams divided into five groups A, B, C, D and E using (ABAQUS) program using 3D model. All analyzed beams have over all depth $60 \mathrm{~cm}$ and $30 \mathrm{~cm}$ width. All beams were analyzed under two points static loading up to failure. Steel reinforcement of all beams have three bars $12 \mathrm{~mm}$ diameter as compression reinforcement, two bars $12 \mathrm{~mm}$ diameter and two bars $16 \mathrm{~mm}$ or four bars $16 \mathrm{~mm}$ as main reinforcement, and The stirrups were $8 \mathrm{~mm}$ diameter having a variable spacing. The concrete strength of analyzed beams 250,400 and $700 \mathrm{~kg} / \mathrm{cm}^{2}$ and a/d ratio 1, 2, 3, 4 and 6 .

Details of the analyzed beams are given in Figs. (1. a), (1. b) and (1. c). The analysis program is given in table (1). This program consists of five groups A, B, C, D and E.

Journal of Engineering Sciences, Assiut University, Faculty of Engineering, Vol. 41, No. 5, September, 2013, E-mail address: jes@aun.edu.eg 
Walaa Shoupk, et al, Theoretical Study on Static Shear Behavior of High Strength Concrete Beams Compared with Normal Strength Concrete Beams, pp. 1753 - 1764

Table 1.

analyzed specimens

\begin{tabular}{|c|c|c|c|c|c|c|c|}
\hline $\begin{array}{c}\text { Secondary } \\
\text { Group }\end{array}$ & $\begin{array}{c}\text { Beam } \\
\text { NO. }\end{array}$ & $\begin{array}{l}\text { Length } \\
\text { of beam }\end{array}$ & $\underset{(\mathbf{c m})}{\mathrm{a}}$ & $\begin{array}{c}\text { a/d } \\
\text { ratio }\end{array}$ & $(\mathrm{kg} /)$ & $\underset{(\mathbf{c m})}{\mathrm{S}}$ & $\begin{array}{l}\text { Main steel } \\
\text { ratio }\end{array}$ \\
\hline \multirow{4}{*}{ A 1} & A11 & 160 & 57.5 & 1 & 250 & 5 & $0.268 \%$ \\
\hline & A12 & 160 & 57.5 & 1 & 250 & 10 & $0.268 \%$ \\
\hline & $\mathbf{A 1 3}$ & 160 & 57.5 & 1 & 250 & 15 & $0.268 \%$ \\
\hline & A14 & 160 & 57.5 & 1 & 250 & 20 & $0.268 \%$ \\
\hline \multirow{4}{*}{ A 2} & A21 & 160 & 57.5 & 1 & 400 & 5 & $0.268 \%$ \\
\hline & $\overline{\mathrm{A} 22}$ & 160 & 57.5 & 1 & 400 & 10 & $0.268 \%$ \\
\hline & $\mathbf{A 2 3}$ & 160 & 57.5 & 1 & 400 & 15 & $0.268 \%$ \\
\hline & A24 & 160 & 57.5 & 1 & 400 & 20 & $0.268 \%$ \\
\hline \multirow{4}{*}{ A 3} & A31 & 160 & 57.5 & 1 & 700 & 5 & $0.268 \%$ \\
\hline & A32 & 160 & 57.5 & 1 & 700 & 10 & $0.268 \%$ \\
\hline & $\mathbf{A 3 3}$ & 160 & 57.5 & 1 & 700 & 15 & $0.268 \%$ \\
\hline & A34 & 160 & 57.5 & 1 & 700 & 20 & $0.268 \%$ \\
\hline \multirow{4}{*}{ B 1} & B11 & 320 & 114 & 2 & 250 & 5 & $0.268 \%$ \\
\hline & B12 & 320 & 114 & 2 & 250 & 10 & $0.268 \%$ \\
\hline & B13 & 320 & 114 & 2 & 250 & 15 & $0.268 \%$ \\
\hline & B14 & 320 & 114 & 2 & 250 & 20 & $0.268 \%$ \\
\hline \multirow{4}{*}{ B 2} & B21 & 320 & 114 & 2 & 400 & 5 & $0.268 \%$ \\
\hline & B22 & 320 & 114 & 2 & 400 & 10 & $0.268 \%$ \\
\hline & B23 & 320 & 114 & 2 & 400 & 15 & $0.268 \%$ \\
\hline & B24 & 320 & 114 & 2 & 400 & 20 & $0.268 \%$ \\
\hline \multirow{4}{*}{ B 3} & B31 & 320 & 114 & 2 & 700 & 5 & $0.268 \%$ \\
\hline & B32 & 320 & 114 & 2 & 700 & 10 & $0.268 \%$ \\
\hline & $\mathbf{B 3 3}$ & 320 & 114 & 2 & 700 & 15 & $0.268 \%$ \\
\hline & B34 & 320 & 114 & 2 & 700 & 20 & $0.268 \%$ \\
\hline \multirow{4}{*}{ C 1} & C11 & 480 & 171 & 3 & 250 & 5 & $0.402 \%$ \\
\hline & C12 & 480 & 171 & 3 & 250 & 10 & $0.402 \%$ \\
\hline & $\mathrm{C13}$ & 480 & 171 & 3 & 250 & 15 & $0.402 \%$ \\
\hline & C14 & 480 & 171 & 3 & 250 & 20 & $0.402 \%$ \\
\hline \multirow{4}{*}{ C 2} & C21 & 480 & 171 & 3 & 400 & 5 & $0.402 \%$ \\
\hline & $\mathrm{C22}$ & 480 & 171 & 3 & 400 & 10 & $0.402 \%$ \\
\hline & $\mathrm{C23}$ & 480 & 171 & 3 & 400 & 15 & $0.402 \%$ \\
\hline & C24 & 480 & 171 & 3 & 400 & 20 & $0.402 \%$ \\
\hline \multirow{4}{*}{ C 3} & C31 & 480 & 171 & 3 & 700 & 5 & $0.402 \%$ \\
\hline & $\mathrm{C32}$ & 480 & 171 & 3 & 700 & 10 & $0.402 \%$ \\
\hline & C33 & 480 & 171 & 3 & 700 & 15 & $0.402 \%$ \\
\hline & C34 & 480 & 171 & 3 & 700 & 20 & $0.402 \%$ \\
\hline D 1 & D11 & 640 & 228 & 4 & 250 & 5 & $0.402 \%$ \\
\hline
\end{tabular}

Journal of Engineering Sciences, Assiut University, Faculty of Engineering, Vol. 41, No. 5, September, 2013,E-mail address: jes@aun.edu.eg 
Walaa Shoupk, et al, Theoretical Study on Static Shear Behavior of High Strength Concrete Beams Compared with Normal Strength Concrete Beams, pp. 1753 - 1764

\begin{tabular}{|c|c|c|c|c|c|c|c|}
\hline $\begin{array}{l}\text { Secondary } \\
\text { Group }\end{array}$ & $\begin{array}{c}\text { Beam } \\
\text { NO. }\end{array}$ & $\begin{array}{l}\text { Length } \\
\text { of beam }\end{array}$ & $\begin{array}{c}\mathbf{a} \\
(\mathbf{c m})\end{array}$ & $\begin{array}{c}\text { a/d } \\
\text { ratio }\end{array}$ & $(\mathrm{kg} /)$ & $\begin{array}{c}\mathrm{S} \\
(\mathrm{cm})\end{array}$ & $\begin{array}{l}\text { Main steel } \\
\text { ratio }\end{array}$ \\
\hline & D12 & 640 & 228 & 4 & 250 & 10 & $0.402 \%$ \\
\hline & D13 & 640 & 228 & 4 & 250 & 15 & $0.402 \%$ \\
\hline & D14 & 640 & 228 & 4 & 250 & 20 & $0.402 \%$ \\
\hline \multirow{4}{*}{ D 2} & D21 & 640 & 228 & 4 & 400 & 5 & $0.402 \%$ \\
\hline & D22 & 640 & 228 & 4 & 400 & 10 & $0.402 \%$ \\
\hline & D23 & 640 & 228 & 4 & 400 & 15 & $0.402 \%$ \\
\hline & D24 & 640 & 228 & 4 & 400 & 20 & $0.402 \%$ \\
\hline \multirow{4}{*}{ D 3} & D31 & 640 & 228 & 4 & 700 & 5 & $0.402 \%$ \\
\hline & D32 & 640 & 228 & 4 & 700 & 10 & $0.402 \%$ \\
\hline & D33 & 640 & 228 & 4 & 700 & 15 & $0.402 \%$ \\
\hline & D34 & 640 & 228 & 4 & 700 & 20 & $0.402 \%$ \\
\hline \multirow{4}{*}{ E 1} & E11 & 960 & 342 & 6 & 250 & 5 & $0.536 \%$ \\
\hline & E12 & 960 & 342 & 6 & 250 & 10 & $0.536 \%$ \\
\hline & E13 & 960 & 342 & 6 & 250 & 15 & $0.536 \%$ \\
\hline & E14 & 960 & 342 & 6 & 250 & 20 & $0.536 \%$ \\
\hline \multirow{4}{*}{ E 2} & E21 & 960 & 342 & 6 & 400 & 5 & $0.536 \%$ \\
\hline & E22 & 960 & 342 & 6 & 400 & 10 & $0.536 \%$ \\
\hline & E23 & 960 & 342 & 6 & 400 & 15 & $0.536 \%$ \\
\hline & E24 & 960 & 342 & 6 & 400 & 20 & $0.536 \%$ \\
\hline \multirow{4}{*}{ E 3} & E31 & 960 & 342 & 6 & 700 & 5 & $0.536 \%$ \\
\hline & E32 & 960 & 342 & 6 & 700 & 10 & $0.536 \%$ \\
\hline & E33 & 960 & 342 & 6 & 700 & 15 & $0.536 \%$ \\
\hline & E34 & 960 & 342 & 6 & 700 & 20 & $0.536 \%$ \\
\hline
\end{tabular}

Where $f_{c}$ is the concrete compressive strength $\left(\mathrm{kg} / \mathrm{cm}^{2}\right), S$ is stirrup spacing $(\mathrm{cm})$.

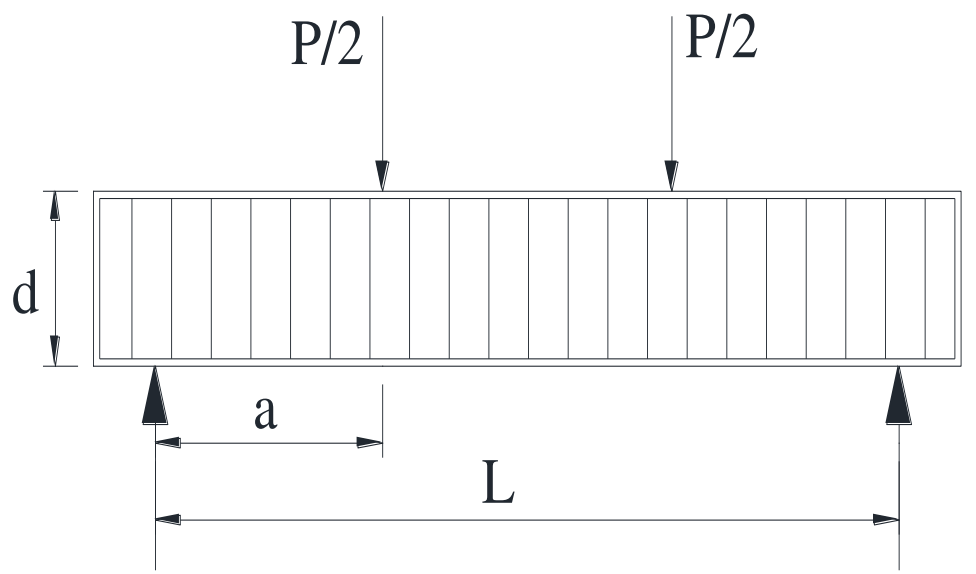

Fig. 1. a. details of beams having vertical stirrups

Journal of Engineering Sciences, Assiut University, Faculty of Engineering, Vol. 41, No. 5, September, 2013,E-mail address: jes@aun.edu.eg 
Walaa Shoupk, et al, Theoretical Study on Static Shear Behavior of High Strength Concrete Beams Compared with Normal Strength Concrete Beams, pp. 1753 - 1764

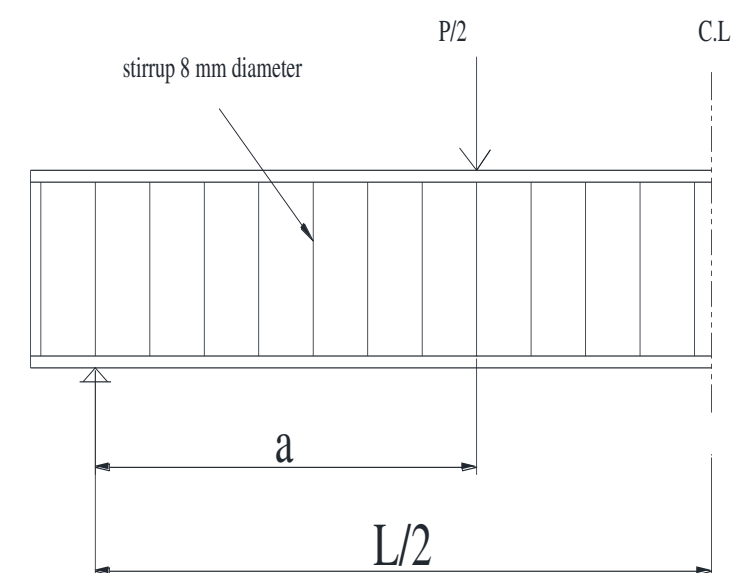

Fig. 1. b. details of beams

$$
\mathrm{b}=30 \mathrm{~cm}
$$

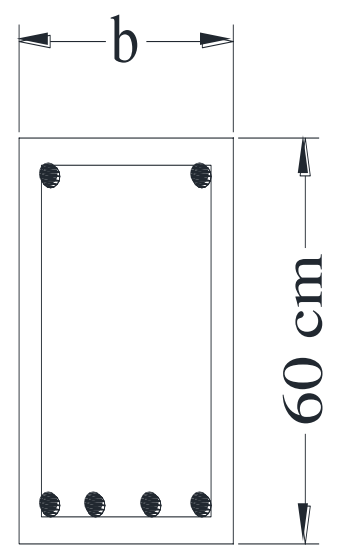

Fig. 1. c. cross section of analyzed specimens

\section{Analysis Results and Discussions}

\section{1. Load-deflection diagrams}

At the position of mid-span, the deflection measured values have been plotted against the corresponding applied loads from starting of loading up to failure as shown in Figs (2) to (4).

Journal of Engineering Sciences, Assiut University, Faculty of Engineering, Vol. 41, No. 5, September, 2013,E-mail address: jes@aun.edu.eg 
Walaa Shoupk, et al, Theoretical Study on Static Shear Behavior of High Strength Concrete Beams Compared with Normal Strength Concrete Beams, pp. 1753 - 1764

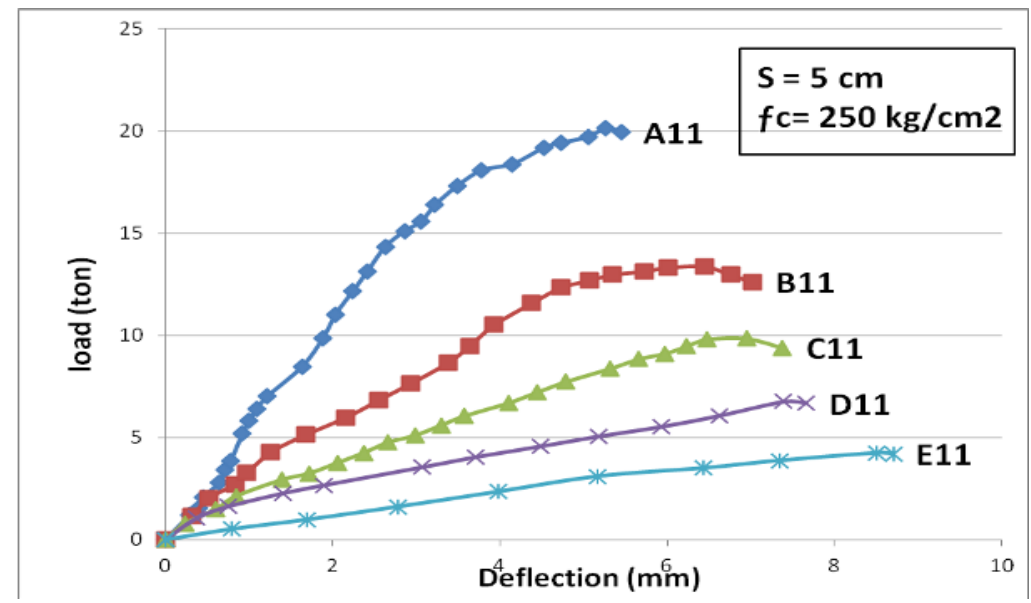

Fig. 2. Load-Deflection relationship for beams with different a/d ratios

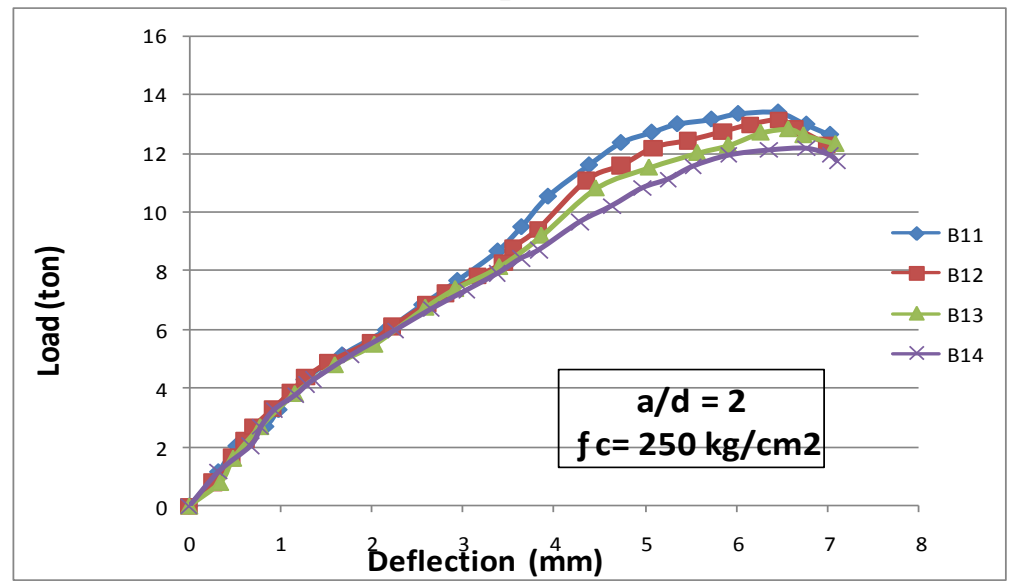

Fig. 3. Load-Deflection relationship for beams with different spacing of stirrups

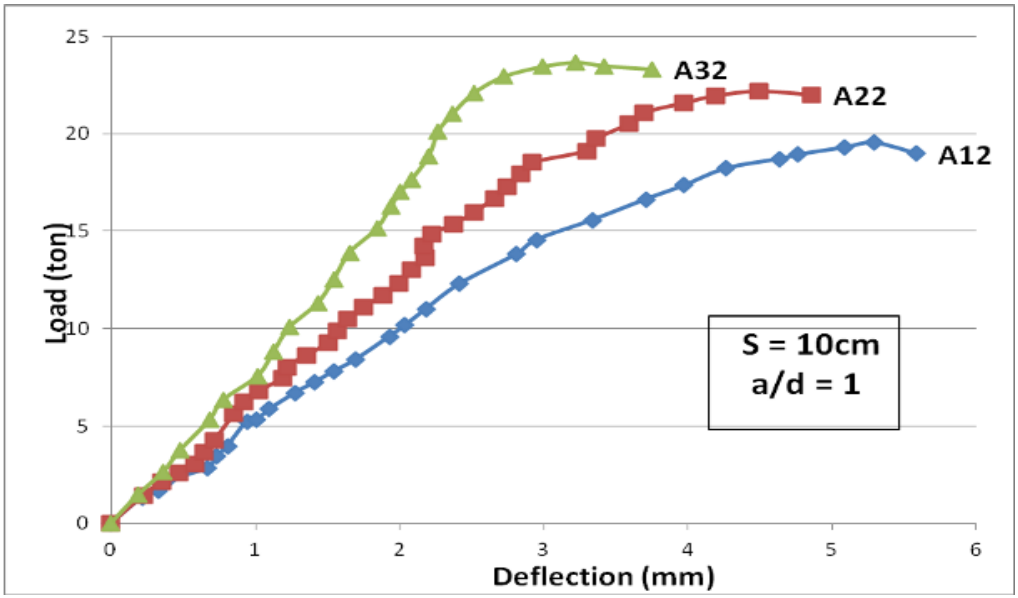

Fig. 4. Load-Deflection relationship for beams with different concrete strength Journal of Engineering Sciences, Assiut University, Faculty of Engineering, Vol. 41, No. 5, September, 2013, E-mail address: jes@aun.edu.eg 
Walaa Shoupk, et al, Theoretical Study on Static Shear Behavior of High Strength Concrete Beams Compared with Normal Strength Concrete Beams, pp. 1753 - 1764

5. 2. Effect of compressive strength

The increasing of concrete compressive strength is led to the increase of the cracking load and ultimate load for concrete grades C250, C400 and C700. The concrete strength affects the deflection as it can be noticed that the measured deflection at a certain load decreases as the compressive strength increase.

\section{3. Effect of shear reinforcement}

It is obvious that the cracking and ultimate load values decreases with the increase of spacing of stirrups. Increasing of the spacing of stirrups leads to a decrease of the maximum measured deflection for beams of either normal or high strength concrete. This means that as the stirrups increased in the beam, the ductility of that beam increases. Also, a decrease of the spacing of stirrups (increasing shear reinforcement) leads to a decrease of the maximum measured stirrup strain for the beams of grade C250, C400 and C700. As the number of stirrups in the beam increases, the shear load of one stirrup decreases. And this small shear load causes the stirrup not to be highly stressed.

\section{Proposed Equations for Cracking and Ultimate Shear Strength}

From results and the parametric analysis it appears that the cracking shear strength for R.C. beams depends mainly on the concrete strength $\left(f_{\mathscr{E}}\right)$, the a/d ratio, and the amount of web reinforcement (spacing and ${ }^{A_{\varpi}}$ ). Based on best fit method and using a statistical program, the equation (1) is proposed to calculate the cracking shear strength for R.C. beams

$$
v_{c r}=0.559\left(\sqrt{f_{c}} \times \frac{a}{d}\right)+0.359\left(\frac{\rho_{w v^{2}} f_{\text {Yw }}}{\sin \alpha}\right)-1.58 \quad \mathrm{~kg} / \mathrm{cm}^{2}
$$

Also from results and the parametric analysis it appears that the ultimate shear strength for R.C. beams depends mainly on the concrete strength $\left(f^{\circ}\right)$, the a/d ratio, and the amount of web reinforcement (spacing and ${ }^{A_{\varpi}}$ ). Based on best fit method and using a statistical program, the equation (2) is proposed to calculate the ultimate shear strength for R.C. beams.

$$
v_{\mathrm{ux}}=2.754\left(\sqrt{f_{0}} \times \frac{d}{\alpha}\right)+0.205\left(\frac{\rho_{\mathrm{wg}} f_{\mathrm{yw}}}{\sin \alpha}\right)-3.71 \mathrm{~kg} / \mathrm{cm}^{2}
$$

Where

$f_{0} \quad$ the concrete compressive strength in $\mathrm{kg} / \mathrm{cm}^{2}{ }_{\text {, }}$

$d / a \quad$ the depth to shear span ratio,

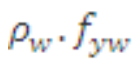

a

$$
\begin{aligned}
& \text { the shear relinforcement index }\left(\mathrm{kg} / \mathrm{cm}^{2}\right) \text {, } \\
& \text { the inclination angle of stirrups. }
\end{aligned}
$$

Journal of Engineering Sciences, Assiut University, Faculty of Engineering, Vol. 41, No. 5, September, 2013,E-mail address: jes@aun.edu.eg 
Walaa Shoupk, et al, Theoretical Study on Static Shear Behavior of High Strength Concrete Beams Compared with Normal Strength Concrete Beams, pp. 1753 - 1764

Comparison between the predicted cracking and ultimate shear strength from proposed equations (1) and (2) with the analyzed cracking and ultimate shear strengths is given in Fig. (5) and (6).

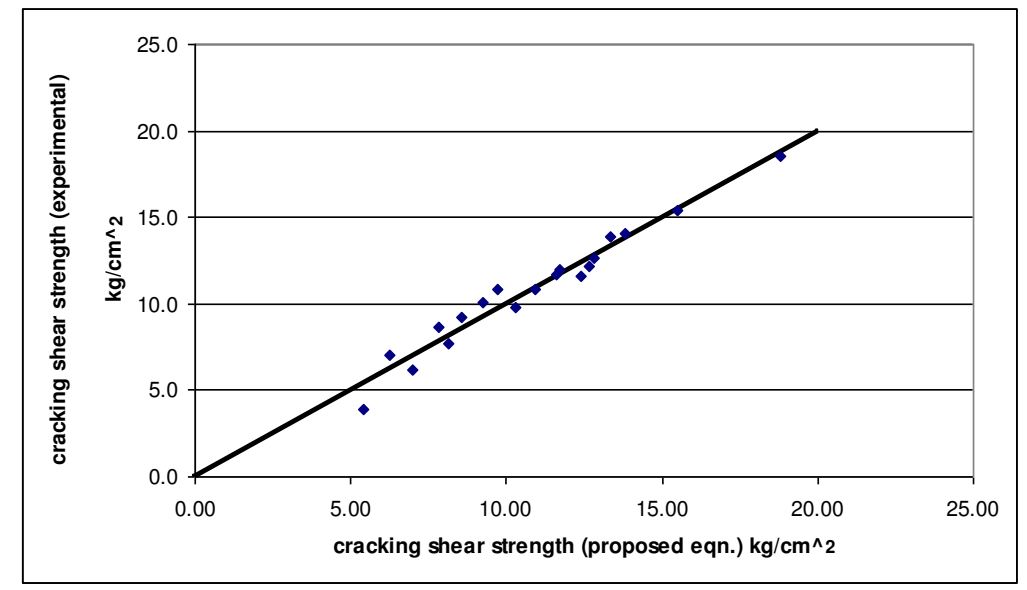

Fig. 5. Cracking shear strength versus calculated cracking shear strength

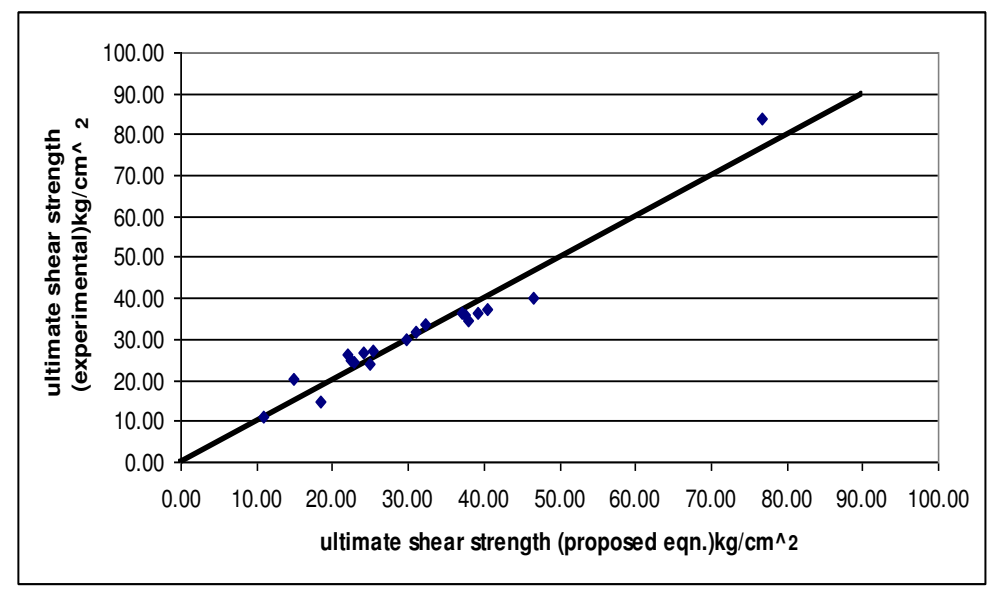

Fig. 6. Ultimate shear strength versus calculated ultimate shear strength

\section{Ultimate Shear Capacity Adopted By the ACI Code of Practice}

The present ACI code of practice (3) assumes that in beams with web reinforcement, the amount of shear stress resisted by the concrete at ultimate is equal to the amount of shear stress that would cause diagonal tension cracking. The amount of shear strength of the concrete was based and determined from analysis results on beams without web

Journal of Engineering Sciences, Assiut University, Faculty of Engineering, Vol. 41, No. 5, September, 2013,E-mail address: jes@aun.edu.eg 
Walaa Shoupk, et al, Theoretical Study on Static Shear Behavior of High Strength Concrete Beams Compared with Normal Strength Concrete Beams, pp. 1753 - 1764

reinforcement and with concrete compressive strengths up to $401.1 \mathrm{~kg} / \mathrm{cm}^{2}$. The shear strength of concrete without shear reinforcement is given by

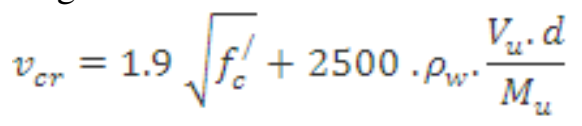

And not greater than $3.5^{\circ}$

$$
v_{\mathrm{us}}=v_{\mathrm{cor}}+\frac{A_{\mathrm{at}} \cdot f_{Y}}{b \cdot s}
$$

Where $f_{\sigma}$ cylinder compressive strength (Psi), ${ }^{\rho_{v s}}$ main reinforcement ratio, ${ }^{A_{a t}}$ area of stirrups in spacing $\mathrm{S},{ }^{v_{\text {Cr }}}$ and ${ }^{v_{\mathbb{L}}}$ are in Psi units.

\section{Comparison between the ACI Code and Analysis Cracking and Ultimate Shear Strength}

From Figs. (7) and (8), it can be noticed that the ACI code equations for predicting cracking shear strength of R.C beams gives values smaller than the analytical values for beams of a/d $=1.0$ and greater than that of beams of a/d equal to 2, 3, 4 and 6 for normal and high strength concrete beams. Also the ACI code equation underestimate the effect of the concrete strength in high strength concrete.

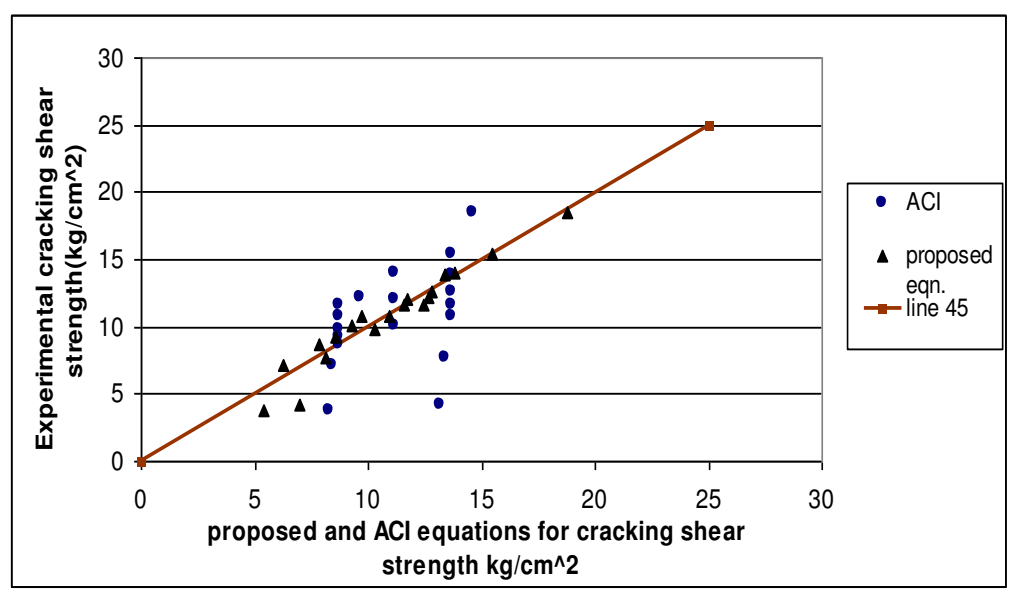

Fig. 7. Comparisons between analytical and predicted cracking shear strengths based on proposed equation (1) and ACI codes

Journal of Engineering Sciences, Assiut University, Faculty of Engineering, Vol. 41, No. 5, September, 2013, E-mail address: jes@aun.edu.eg 
Walaa Shoupk, et al, Theoretical Study on Static Shear Behavior of High Strength Concrete Beams Compared with Normal Strength Concrete Beams, pp. 1753 - 1764

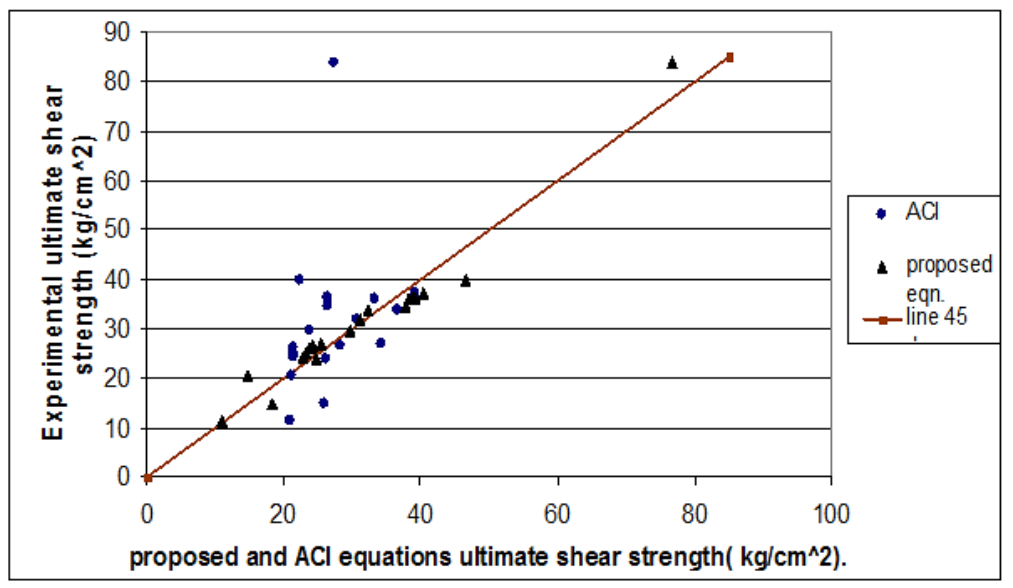

Fig. 8. Comparisons between analytical and predicted ultimate shear strengths based on proposed equation (2) and ACI codes

\section{Conclusions and Remarks}

On the basis of the results obtained in this study, the following conclusions have been reached:

1- Increasing the compressive strength and the amount of shear reinforcement leads to an increase of the cracking and ultimate shear strengths.

2- Increasing the amount of shear reinforcement leads to an increase in the beam ductility, so the minimum amount of shear reinforcement must be increased for high strength concrete.

\section{References}

[1] ACI committee 318, Building Code Requirements for Reinforced Concrete (ACI 318-99).

[2] Khairy Hassan A., "Finite Element Study on Shear Behavior of RC Beams with HSC" ${ }^{S T}$ Int, conference of civil Eng. Science, ICCESI, Vol.1, 835-845, Oct.2003.

[3] Imran A. Bukhari, Saeed Ahmad "Evaluation of Shear Strength of High-Strength Concrete Beams Without Stirrups" The Arabian for Science and Engineering, October 2008.

[4] Karam Abdou Awad "Experimental Study on Static Shear Behavior of High Strength Concrete Beams Compared with Normal Strength Concrete Beams" Journal of Engineering Sciences (JES), November 2009.

[5] Sudheer Reddy L., Ramana Rao .N.V., Gunneswara Rao T.D.

Shear Resistance of High Strength Concrete Beams Without Shear Reinforcement" Internatio nal Journal of Civil and Structural Engineering, Vol.1,No. 1,0976-4399, 2010.

[6] Sudheer Reddy L., Ramana Rao N. V., and Gunneswara Rao T. D. "Evaluation of Shear Resistance of High Strength Concrete Beams Without Web Reinforcement Using ANSYS" The Arabian for Science and Engineering, Vol.6, No. 2, February 2011.

[7] B.K.Kolhapure "Study on Shear Behavior of High Strength Concrete (HSC) Slender Beams" International Journal of Engineering and Advanced Technology (IJEAT), Vol.2, 2249-8958, June 2013.

Journal of Engineering Sciences, Assiut University, Faculty of Engineering, Vol. 41, No. 5, September, 2013,E-mail address: jes@aun.edu.eg 
Walaa Shoupk, et al, Theoretical Study on Static Shear Behavior of High Strength Concrete Beams Compared with Normal Strength Concrete Beams, pp. 1753 - 1764

\section{دراسة نظرية عن سلوك القص الاستاتيكي في الكمرات عالية المقاومة

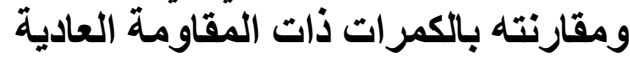

الملخص العربى

في هذه الدراسة تم تحليل ستون كمرة خرسانية ذات رتب خرسانية مختلفة باستخدام برنامج تحليل بسمى

$$
\text { 1. Abaqus }
$$

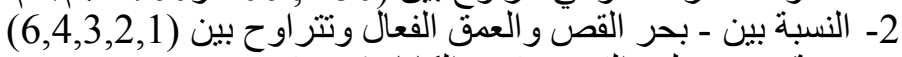

$$
\begin{aligned}
& \text { 3- نسبة حديد تسليح القص بـ (عدد الكانات/منر ) }
\end{aligned}
$$

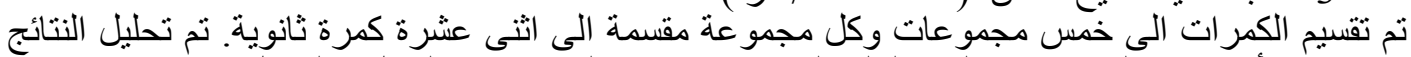

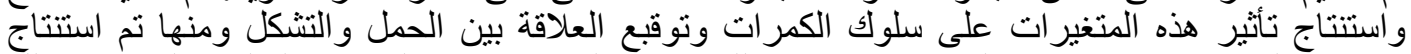

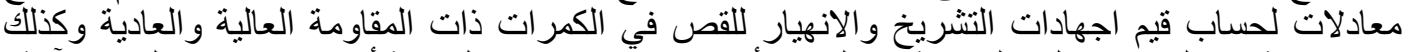

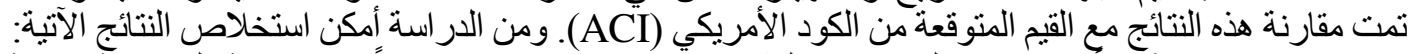

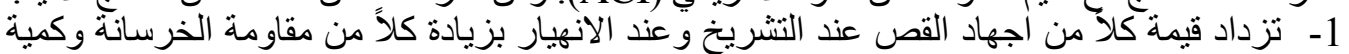

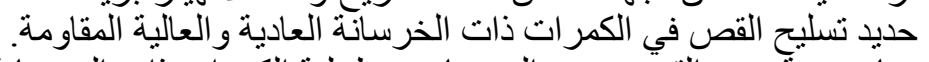

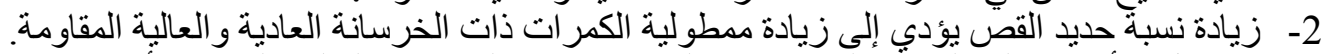

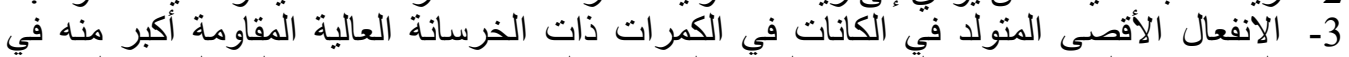

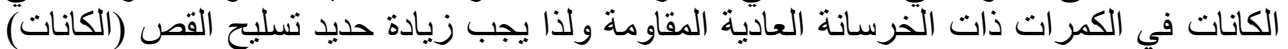
بزيادة رتبةً الخرسانة.

Journal of Engineering Sciences, Assiut University, Faculty of Engineering, Vol. 41, No. 5, September, 2013, E-mail address: jes@aun.edu.eg 